\title{
Thinking Outside the Compound: Turkey's Approach to Peacebuilding in Somalia
}

\author{
Onur Sazak and Auveen Elizabeth Woods
}

\section{INTRODUCTION}

Turkey's engagement in Somalia is one of the most visible examples of a rising power's approach to a conflict-affected country. Since its highprofile intervention during the height of the famine in 2011, Turkey has elevated its level of engagement with Somalia and has committed to robust humanitarian assistance, development aid, and civilian capacity to resuscitate the fragile state. Over the years, a "Turkish model" of engagement has emerged. It is characterized by the quick delivery of assistance and programs with Turkish personnel on the ground. The Turkish model is also noted for its emphasis on soft power attributes such as business interests and cultural affinity such as Turkey's Muslim identity. This approach is in contrast to other "traditional donors" in Somalia who are often accused of being overly bureaucratic, slow, and isolated, either bunkered in the airport in Mogadishu or providing aid remotely from other neighboring countries (Wasuge 2016).

However, there are a myriad of actors with different interests and objectives engaged in the country. These range from the neighboring states of

O. Sazak $(\square) \bullet$ A.E. Woods

Sabancı University, Istanbul, Turkey

(C) The Author(s) 2017

C.T. Call, C. de Coning (eds.), Rising Powers and

Peacebuilding, Rethinking Peace and Conflict Studies, DOI 10.1007/978-3-319-60621-7_8 
Djibouti, Kenya, and Ethiopia, to traditional donors such as the United Nations and the UK, as well as more recent regional actors such as South Africa, the United Arab Emirates (UAE), and Turkey. Despite the longevity and level of financial investment, none of these actors have received the level of international attention that Turkey has since its high-profile intervention in the country in 2011. This chapter seeks to shed light on Turkey's activities in Somalia, particularly its approach to peacebuilding. It draws on interviews with Somalis to explore their perspectives on Turkey's engagement, while also placing these activities firmly in the context of other external actors in the country and Somalia's conflict dynamics.

\section{SOMALIA CONTEXT}

On February 8, 2017, Mohamed Abdullahi Mohamed (Farmajo) was elected as the ninth president of the Federal Republic of Somalia. He has inherited a weak and fractured state, with the previous government failing to achieve many of the benchmarks it set for itself when it came to power in 2012 (Arman 2017). Much of the lack of progress stems from the fragile nature of the state-as one recovering from a long civil war. This is a point put succinctly by the Finnish Minister for International Development, Pekka Haavisto: "When fragile states lack legitimacy and the trust of their own people, rapid state-building efforts can actually work against rather than for peace building, inspiring resistance from those who fear how state authorities will wield their new power" (Menkhaus 2014). On top of that, Al-Shabaab continues to launch attacks on the government and the African Union Mission in Somalia (AMISOM), upon which the government is dependent upon for its existence. Adding to the government's challenges is the high number of internally displaced people (IDPs) in the country. There are an estimated 1.1 million IDPs in Somalia, with 369,000 people thought to be displaced in and around Mogadishu alone (UNHCR 2016). Most are headed by women. About 4.9 million people are in need of humanitarian assistance (UNHCR 2016). Additionally, there are third-generation Somalis in refugee camps in Yemen, Ethiopia, Djibouti, and Kenya who are slowly returning to the country and pose a unique security risk as a vulnerable group. There is also continued animosity among the different clans and regional administrations such as Puntland and Jubaland, who simply do not trust the fledging federal state.

The root cause of Somalia's current predicament was the collapse of the Somali state infrastructure in 1991. While there had been increasing 
interclan warfare and atrocities since the late 1970s, the overthrow of the Siad Barre government (1969-1991) and the destruction of state institutions instigated over two decades of conflict and fragility that the country has yet to recover from. In the absence of an effective government, warlords and armed groups loosely affiliated to clans have vied with each other for power and dominance throughout the country. The current structure of the Federal Government is still based on the exclusionary 4.5 formula. This equally distributes seats among the four major Somali clans (the Darod, Dir, Hawiye, and the Digil and Mirifle). The minority clans, who are sometimes referred to as the Fifth Clan, are together allotted just half the number of seats of one whole clan receiving 0.5 percent representation. This is a deeply unequal system that sidelines all minority class, regardless of their population size.

The two main sources of conflict in Somalia are the clan structure of Somali society and competition over resources and their distribution (Somali Peace Line 2016). This has been particularly prevalent regarding the role of the state and its resources. Clans are a source of patronage, security, and justice for most Somalis-a status that has only been heightened in the stateless paralysis of the country. On the one hand, there is a strong culture of blood revenge or alternatively blood compensation (Diya) that can further heighten conflict. On the other hand, the clan system is also the source of traditional Somali conflict-resolution methods such as the Shir Beeleed (clan assembly), led by the clan Elders or Guurti. The Shir Beeleed is a slow and time-consuming negotiation and dialogue technique that can last for weeks or even months (Balthasar 2013).

This delicate balance between peace and conflict in the clan system has been further exacerbated by international interventions and meddling by neighboring countries, ostensibly due to security concerns. Since the Cold War, development and humanitarian aid has been diverted into the Somali war economy, first under President Siad Barre and later by clans. In the early 1990s, a series of UN-led peace operations attempted to support a statebuilding process and provide security for aid workers in the spiraling insecurity and famine ravaging the country. These missions, however, quickly became mired in the politicization of aid and became targets of the worsening interclan and warlord infighting (Harper 2012). The situation continued to escalate, culminating in the infamous Black Hawk Down incident in 1993 and the withdrawal of USA and other troop-contributing countries. 
The result of these debacles has been enduring. A decade would pass before the next generation of peacekeepers arrived in Somalia with the launch of AMISOM in 2007. Meanwhile, the neutrality and security of humanitarian aid workers were compromised by these events, forcing donors to relocate their headquarters and international staff away from Somali communities and adopt a hands-off approach. This often meant operating outside the country, for example, in Nairobi, and employing intermediaries inside Somalia to deliver aid. The result of this approach meant that Somali recipients were burdened by a slow, bureaucratic aid system with little to no consultation with communities and the frequent diversion of aid into local war economies. This long-distance approach is the modus operandi that developed for many traditional donors working on Somalia. Traditional donors are often identified as state agencies or international NGOs from Development Assistance Committee (DAC) countries of the Organization for Economic Co-operation and Development (OECD), such as Norway, the USA, Italy, and Canada.

Since the mid-1990s, Somalia has been the site of proxy wars among Ethiopia, Kenya, Eritrea, and Djibouti, all of whom have, at times, allied with various Somali clans, regional administrations, or political groupings in order to destabilize a rival or gain access to a resource. Ethiopia invaded Somalia in 2006 to oust the Union of Islamic Courts (UIC) in southcentral Somalia. While this was achieved quickly, Ethiopia was forced to stay until 2009 to prop-up the unpopular but internationally recognized Transitional Government of Somalia. It was in response to the harsh counter-insurgency operations employed by Ethiopia that Al-Shabaab emerged (International Crisis Group 2012). Ethiopia and Kenya continue to align with regional administrations in Somalia to support a federal system with a weak central Somali state. The decision to add Ethiopian and Kenyan soldiers to AMISOM alongside Ugandan and Burundian troops has been considered a controversial move given the hostility and suspicion most Somalis feel toward both countries (Geeska Africa Online 2015).

\section{Turkish Foreign Policy Priorities: Explaining Turkey's InVOLVEMENT in SOMALIA}

Much has been made of Turkey's high-profile intervention into the devastating 2011 famine that stalked south central Somalia. The perceptions regarding this singular event often belie the historical relations between the two countries and the growing interest of Turkish authorities in 
Somalia in the years preceding it. Turkish and Somali officials have emphasized the historical relations between both countries, which stretch back to the Ottoman Empire in the sixteenth century. At the height of World War I, the Ottomans armed Somalis in their rebellion against the British. Despite a cessation in Somali-Turkish relations for much of the Cold War, Somalia was nonetheless one of the few locations in Africa where a Turkish embassy was opened, in 1979. The embassy remained active until its closure in 1991 at the beginning of the country's civil war. It was reopened on November 1, 2011. With the exception of General Çevik Bir as force commander for UN Mission to Somalia (UNOSOM II) in 1993, the Turkish state had no relationship with Somali authorities until the visit of President Sheikh Sharif of the Transitional Federal Government in 2009, which began to pique the interest of Turkish authorities. ${ }^{1}$

There are a number of factors that underpin Turkey's engagement in Somalia. Humanitarianism was the underlying motive behind Turkey's initial engagement in 2011. At the height of the famine, which coincided with the holy month of Ramadan in August 2011, a period of fasting and charity, a huge public awareness campaign was run by Turkish NGOs and celebrities showing images of emancipated women and children. The impact of this campaign was decisive in mobilizing the Turkish public and state attention on the plight in Somalia. An estimated \$57 million was raised from private donations alone (TIKA 2013) while around 500 Turkish nationals arrived in Mogadishu to help deliver aid (Lough 2012).

Humanitarian aspirations remain a motivation for Turkish engagement in Somalia. In March 2011, Turkey gave \$122 million work of humanitarian aid to Somalia (Daily Sabah 2017). Turkey's broader activities, however, should also be seen within the broader foreign policy priorities context, in particular Turkey's image as rising power. Over the past few years, Turkey has pursued a range of activities such as gaining a seat at the UN Security Council (2009-2010), high-profile events like the World Humanitarian Summit in 2016 and increased commitment to aid and security support in general. Between 2012 and 2014 alone, Turkey's Official Development Assistance (ODA) increased by nearly 30 percent from $\$ 1.2$ billion in 2012 to $\$ 3.6$ billion in 2014 (TIKA 2014). Turkey's desire to promote its image as a rising power is succinctly highlighted by a 2012 Turkish International Cooperation and Coordination Agency (TIKA) report that states, "In 2012, there has been a decrease in the amount of development assistance provided by traditional donors; whereas Turkey's development assistance increased by $98.7 \%$ in one year. In this framework, Turkey is 
now defined as an "emerging donor" and strengthens its "donor" role each passing year" (TIKA 2013, 21).

In many ways, Somalia has become an opportunity for Turkey to illustrate not only its commitment to addressing shared international issues, but also to project its image as a rising power. Turkey's discourse reflects these aspirations. At the UN's High-Level Partnership Forum on Somalia in Istanbul in February 2016, President Erdoğan said, "Somalia, which was on the verge of destruction and totally hopeless back in 2011, is rising to its feet with the efforts we and our international partners make... With Somalia, the Turkish model of aid has gained recognition in literature" (Presidency of the Turkish Republic 2016). Such discourse is aimed not only at the international community but also at Turkey's own citizens. Turkey's engagement in Somalia, for example, has boosted the image of the ruling Justice and Development Party (AKP) and its leader Tayyip Erdoğan, appealing in particular to the Party's constituency of conservative and religious voters (Sucuoglu and Stearns 2016).

In addition to being an example of Turkey's rising power status, Somalia should also be seen in the context of Ankara's efforts to expand its economic and political relations. Over the past decade, Turkey has expanded its engagement in areas beyond its traditional sphere of the Balkans, the Middle East, and Central Asia. In 2014, Turkish ODA reached 29 African countries (TIKA 2016). Like other rising powers, economic interests are intricately linked to Turkey's foreign policy and its aid. In what has become a template replicated in other countries, the Turkish state's presence in Somalia was accompanied by the opening of a new embassy, TIKA offices, new Turkish Airlines routes, and an influx of development programs and commercial activities. Turkish exports to Somalia have increased from an estimated \$3.5 million in 2009 to \$115 million in 2016 (Turkish Statistics Agency 1996-2017). Turkish Airlines has a lucrative route to Mogadishu, and Turkish companies have secured numerous contracts in Somalia.

In February 2016, President Erdoğan and then-President Hassan Sheikh Mohamud co-hosted a Private Sector Investment Conference in Istanbul to promote Turkish investments in Somalia across a range of areas such as energy, information and communications technologies, and agriculture. There has also been interest in Turkish companies expanding beyond Mogadishu to Puntland in the north and Juba in the south (Sucuoglu and Stearns 2016). Additionally, Turkish state aid, which focuses on technical assistance and infrastructure development, combines both economic and development opportunities for Turkey and the recipient country. 
Rebuilding of infrastructure such as roads and construction of hospitals and mosques has created jobs for both local Somalis and Turkish companies (Achilles et al. 2015). Somalia offers not only an untapped market for Turkish businesses but also a gateway into other African countries. Interviewees from Uganda, Burundi, and South Sudan have all expressed interest in Turkey's activities, highlighting its work in Somalia (Rising Powers Conference 2016).

The top three donors of gross ODA for Somalia between 2014 and 2015 were the USA with $\$ 205.4$ million, followed by the UK at \$195 million and Turkey, which provided \$194 million (OECD 2015). EU institutions were the fourth largest donor to Somalia with $\$ 180$ million and Sweden the fifth with $\$ 72$ million (OECD 2015). Turkey is among one of the top donors to Somalia and is the only non-DAC member of this group. Yet its engagement in Somalia differs remarkably.

Soft power has underpinned Turkey's engagement in Somalia. Its image as a relatively prosperous democratic Muslim-majority country with historical ties to the country distinguished Turkey from traditional donors and made it an attractive partner. The visible engagement by Turkish officials and Turkish projects on the ground, and the high visibility of their projects such as from refurbishing buildings, has supported its positive image. Finally, the high-profile visits of President Erdoğan, the opening of Turkey's huge embassy in downtown Mogadishu, and the establishment of direct flights between Mogadishu and Turkey have all bolstered the ties between the two countries. In addition to this use of soft power and cultural affinity, Turkey's engagement in Somalia is characterized by the high visibility of its projects and their quick and direct delivery of aid on the ground. Turkey has a holistic approach, engaging in diplomacy, humanitarian relief, and development programs simultaneously in Somalia. ${ }^{2}$ The Turkish model is also noted for its emphasis on business interests. Interviews with Turkish aid officials, NGO representatives, and beneficiaries on the ground have revealed three central principles that seem to drive Turkey's success. These are unconditionality, bilateralism, and non-securitization of aid and personnel.

Securitization has become more visible in the twenty-first century. Commonly referred to as the "securitization of personnel" or "compounding of aid" (Duffield 2010), representatives of international humanitarian agencies and relief organizations are confined to heavily fortified living and working quarters in conflict zones. These render agents of traditional actors immobile and alien to the needs of beneficiaries on the ground. This 
bunkered mentality has been particularly prevalent in traditional donors' approaches to Somalia since the 1990s. For many years, international diplomats and other personnel that worked on Somalia have been based in Nairobi and fly into the Mogadishu airport for a few hours, staying in the compound, and turn around and depart the same day.

By contrast, Turkey's engagement in Somalia has, in part, been defined by the presence of officials and personnel on the ground. While security is taken seriously with guards at Turkish offices, Turkish personnel still live in Somalia. Turkey has built one of its largest embassies in downtown Mogadishu, where Ambassador Olgan Bekar and other officials live. Turkey's consulate in Hargeisa, Somaliland, is occupied by a Turkish representative. Turkish aid groups, teachers, and others who work on Somalia continue to be based in the county, despite the fragile security situation (Wasuge 2016; Sucuoglu and Stearns 2016). This approach has a number of advantages over the bunkered practices of traditional donors. One is that it reduces the cost of programs by reducing the expense of brokers that are so frequently used by traditional donor agencies and country missions. Their presence on the ground also means that Turkish officials and personnel can react more quickly to changing dynamics. They can better monitor programs and consult with recipients on the quality and relevance of programs. Contrary to traditional donors, Turkey does not have rigid procedures or systems of delivery that must be adhered to. The daily flights provided by Turkish Airlines facilitate greater transportation of products and personnel when necessary.

Turkey works with a number of multilateral initiatives on Somalia. These include signing up with platforms like the New Deal for Somalia, hosting international meetings and supporting AMISOM. Despite this, however, bilateralism in general is still the defining attribute of Turkey's engagement to recipient countries. Roughly 90 percent of all Turkish aid efforts globally are coordinated directly between Turkey and the donor recipient country. For example, in 2014, just 2.4 percent of Turkey's ODA ( $\$ 88$ million out of $\$ 3.6$ billion) was provided through multilateral contributions (TIKA 2016, 11). The main reason why Turkey prefers bilateral arrangements is the effectiveness of this model in expediting the process and delivering tangible results, according to the Turkish officials who have frequently commented on this issue.

There has often been criticism of Turkey for failing to coordinate with donors in Somalia and acting unilaterally. But there are a number of reasons for Turkey to work outside multilateral institutions. Speed and efficiency are highly valued by Turkish officials who are output orientated 
(Sazak et al. 2015, 9). In contrast, Western donors and multilateral institutions focus on processes and systems. Such an approach, while intended to ensure that things are done correctly, is criticized by both Turkish officials and Somalis interviewed, for being too slow and bureaucratic. For example, Turkish diplomats apparently felt frustrated when they attempted to collaborate with AMISOM on training Somali soldiers in 2013. Their plan was met with resistance from some AMISOM partners such as the USA (Wasuge 2016). Frustrated with the lack of progress, Turkey decided to start working with the Somalia National Army bilaterally. Similarly, with the exception of a brief hiatus in 2013, Turkey has provided direct budgetary support to the Federal Government of Somalia. The payments have ranged from $\$ 4.5$ million to $\$ 6$ million in recent years (Olgan Bekar's speech, Rising Powers Conference 2016). This is an aspect of the New Deal that other donors have failed to do, citing concerns with transparency (Hearn 2016).

Some respondents noted that traditional donors' overly bureaucratic approach, with multiple offices, systems, and officials to work with, often overwhelmed and stifled the functioning of the recipient country's fragile state institutions. ${ }^{3}$ Bilateral engagement seems to be more manageable for recipient states. However, the bilateral model also brings out a number of serious coordination problems, especially in the areas of personnel deployment (level of expertise and personnel insurance packages), absence of a reliable monitoring and evaluation model and language constraints. Turkey, nonetheless, remains acutely aware of the international analysis of global dynamics but prefers bilateral development assistance arrangements.

\section{Turkey's Approach to Peacebuilding in Somalia}

Since 2011, the majority of the Turkish state's activities have been engaged primarily in Mogadishu. This remains the case as officials interviewed for this study point out that it is the area with greatest need. Over these years, Turkey has, however, expanded its political engagement to include Somaliland, Kismayo, Puntland, Galkayo, Baidoa, and Beledweyne, among others (Olgan Bekar's speech, Rising Powers Conference 2016). There is no general framework or policy document publicly available that guides such activities or outlines the annual goals of Turkey's work in Somalia. Rather than having their own specific priorities, officials state that they try to develop projects in consultation with Somalis while conscious of their own available capacity and strengths. ${ }^{4}$ 
While each project may not be conceptualized in terms of a grander peacebuilding goal or "reconstruction" as Turkish officials term it, ${ }^{5}$ Turkey's approach to Somalia, particularly south central, falls into two categories: statebuilding and social peacemaking. According to the Turkish Ambassador to Mogadishu, Olgan Bekar, providing humanitarian assistance, development aid, and statebuilding support simultaneously is key to lasting peace and stability in Somalia:

"Peacebuilding and state building in Somalia require a comprehensive approach. This comprehensive approach also requires a humanitarian approach, humanitarian aid, political engagement, security and development assistance... A purely humanitarian approach to protracted conflict areas and conflict-affected countries offers only a short-term solution. Assisting affected countries simultaneously and in tandem with long term development tools increases the resilience and capacity of the beneficiaries. This in the long term reduces the vulnerability and increases the capacity of the recipient local actors to respond to humanitarian crisis themselves." (Rising Powers Conference 2016)

Dr. Kani Torun, Ambassador Bekar's predecessor in Mogadishu, also underlines the indispensability of statebuilding for peace in Somalia:

State building is very important, because I have seen the kind of destruction that can happen to a society without a functional state as a result of a civil war ... [Therefore] state building was our priority; we worked with the state particularly to improve the way in which the state operated ... one area we worked with the government closely was the security area. Turkey worked with the police and army to build strong security forces to provide security. Security investment and other things will come. Even aid is related to security. (Rising Powers Conference 2016)

Turkey's holistic approach encompasses a wide range of projects. This includes rehabilitation of infrastructure such as buildings, institutional capacity building, social service support in communities, and direct engagement on social relations through education initiatives and cultural events. Ambassador Bekar illustrates the virtue of this approach with the Digfer hospital (renamed Erdoğan General Hospital in 2015) in Mogadishu:

We demolished the old Digfer hospital and built a new Mogadishu research and training hospital. This was a big improvement with 220 beds. Then we 
equipped it and sent doctors and nurses and other personnel to run the hospital. But we did not run it on our own; we developed a good partnership with the Somali side and established a joint management with the Somali management staff. Today we provide internships and trainings for young Somali doctors. (Rising Powers Conference 2016)

At the international level, Turkey has been engaged in a number of multilateral initiatives on peacebuilding issues in Somalia. It has participated and hosted peace processes and donor conferences, including the Istanbul I and II conferences with the UN in 2010 and 2012, respectively. The 2012 conference focused on Somalia's post-transition future and brought together over 300 Somali civil society groups (International Crisis Group 2012). Turkish state representatives, including President Erdoğan, have also frequently pushed Somalia up on the international agenda through speeches and statements at UN meetings. Turkey is also a participating state in the Somali New Deal, has hosted its High-Level Partnership Forum in 2016, and is a co-chair with the USA on the working group on security. Signed in March 2013, the New Deal was meant as a guide for external actors engaging in Somalia and outlined a threeyear statebuilding and peacebuilding roadmap (2014-2016). Of the seven states that have signed up to New Deal agreements, Somalia is the only country where the framework has been most successful, being used to define national priorities and align budgets. Prior to this, there were no existing frameworks or strategy agreements with donors, and the Federal Government of Somalia took early ownership of the New Deal to try to assert its burgeoning authority (Hearn 2016, 8).

At an interstate level, there are a range of Turkish ministries, and state and semi-state agencies working in Somalia. These range from TIKA, the Directorate for Religious Affairs (Diyanet), and the Turkish Red Crescent (Kuzılay), to a myriad of State Ministries in the areas of health, education, and defense. Each of these ministries and state agencies are capable of enacting their own bilateral projects. In addition to these actors, the Turkish Ministry of Foreign Affairs and the Office of the Prime Minister have been involved in mediation attempts. There is a disagreement between burgeoning regional administrations such as Puntland, Garowe, and the central government in Mogadishu. The Turkish government has played a role in facilitating talks.

The most high-profile mediations facilitated by Turkey are ongoing discussions between the Somaliland government and the Federal Government 
in Mogadishu (Garowe Online 2016). Some of these mediation attempts have been overseen by former ambassador Dr. Kani Torun, who has initiated talks between the Federal Government and Somaliland. Describing his approach, Dr. Torun says, "When I talked to them, I did not talk the way career diplomats talk ... by the book, if you will. I instead talked as if I were one of them. When they saw my sincerity as well as my open and frank engagement in discussion, they had trust and initiated the talks with the federal government" (Rising Powers Conference 2016). Progress has been slow, but Turkey has succeeded in getting representatives of the Federal Government and Somaliland to talk to each other more often.

Alongside this consistent intra-state engagement, Turkey's programs and approach to Somalia have evolved. Most of the Turkish state aid until 2013 can be classified as humanitarian assistance. ${ }^{6}$ Turkish humanitarian aid dropped from $\$ 77$ million in 2011 to $\$ 27$ million two years later in 2013 (Global Humanitarian Assistance 2014). This aid was largely in the form of emergency food, medical services, and supplies to IDP camps in and around Mogadishu area. Since 2013, the Turkish state engagement in Somalia has focused on capacity-building and technical assistance programs. For example, in 2013, both the Turkish Ministry of Foreign Affairs and the Turkish Central Bank began to provide technical assistance and training to their Somali counterparts (Sazak et al. 2015). The Turkish Ministry of Foreign Affair had been helping its counterpart to establish its own internal server. ${ }^{7}$ Since 2014, Somali diplomats have also participated in bilateral and international training programs with Turkey's Diplomat Academy in Ankara. These exchanges have been accompanied by greater cooperation and training between the Turkish and Somali Armed Forces through two agreements signed in 2010 and 2014 (Today Zaman 2012). Such activities are closely associated with statebuilding and peacebuilding for Turkish officials who argue that fundamental services and institutional capacity need to be strengthened to provide legitimacy to the Federal Government and, therefore, counter the allure of extremists. ${ }^{8}$ Many of these state capacity programs are intended to improve local security and social services.

At a local level, Turkey's education programs such as scholarships, sponsorship of orphanages, and religious-cultural initiatives are specifically aimed at changing dynamics and conditions in local Somali society. ${ }^{9}$ In particular, Turkish officials view education programs as important peacebuilding initiatives that can challenge the allure of extremist narratives. Since 2011, Turkish officials estimate that nearly 3000 scholarships 
have been provided to Somali students from both state and NGOs. ${ }^{10}$ The presence of these initiatives, through the Turkish offices in the country or personnel directly delivering support to communities, also challenges one of the central conflict drivers in the country-brokers. According to one Turkish Red Crescent official, "Our representatives have always delivered their supplies to the recipients' camps on their own without involving any brokers. If the security situation is not conducive for us to go to a certain site, we don't go there, but we also do not entrust our supplies to some third entity who we know would not deliver it to the address it was supposed to go and would make profit out of it by selling it."1l Ongoing security challenges that have targeted them have caused Turkish personnel to be more cautious. And yet, Turkish officials and personnel remain the most visible foreigners in Somalia, particularly in Mogadishu, through their offices and projects (Wasuge 2016).

Since 2013, Turkish peacebuilding in Somalia has also adopted a visible military presence. Turkey's pledge of financial and military training assistance to AMISOM indicated that its activities in Somalia would no longer be limited to humanitarian and development assistance. At the time, Turkey had committed \$1 million financial support to AMISOM and had undertaken the training of a modest number of Somali troops and policemen in Turkey (Achilles et al. 2015). Furthermore, the Turkish military is opening a training facility for the Somali Armed Forces in Mogadishu in 2017. This is Turkey's first military base abroad. Reportedly, to be run by the Turkish Armed Forces personnel, the academy will have up to 200 Turkish officers and is expected to train over 10,000 Somali National Army troops as well as soldiers from other African nations (Hurriyet Daily News 2016). The academy is envisaged as a center for excellence for training missions encompassing the entire continent.

There was another marked shift in Turkey's approach to Somalia in 2015. Turkish public-private enterprises that characterized the frenzied environment until 2013 had evolved. Improvement in domestic security had been accompanied by an increase in private Turkish companies that won contracts in a number of key sectors. Mogadishu's Aden Abdulle International Airport is managed by Favori LLC (Favori LLC Website), as is Mogadishu Port by Albayrak (The Somali Investor 2015). There are also strong signals from bilateral investment conferences and meetings between officials from Turkey and Somalia that Turkish businesses intend to explore new opportunities in provinces such as Puntland (Sucuoglu and Stearns 2016, 25). 
Since 2015, the capacity-building programs of the Turkish state have entered their second stage with a greater emphasis on sustainability and local ownership. This involves the transfer of responsibility and administration of Turkish programs to their Somali counterparts. An example of this is the garbage collection program in Mogadishu. The Turkish government has delivered equipment so that it will be run solely by Somalis. ${ }^{12}$ Similarly, Sifa Hospital in Mogadishu, which is run by the Turkish Health Ministry, is being co-administered with the Somali Ministry of Health. Today, civil training programs are administered either on the ground in Somalia or more often in Turkey partly due to the continued insecurity in the country. ${ }^{13}$

Somalia is still the largest recipient of Turkish aid in Africa, but this is changing. The focus on collaboration and capacity-building programs has resulted in a decline in the spending and projects allocated to Somalia. Turkish officials, however, argue that this does not signal a declining commitment by Turkey. ${ }^{14}$ In 2014 , nearly 70 percent of TIKA's $\$ 8.3$ million budget in Somalia went on health sector-related projects while administrative and civil infrastructure was at 20.5 percent (TIKA 2016, 136). This is equivalent to $\$ 5.7$ million and $\$ 1.6$ million, respectively. These numbers do not include spending from Turkish NGOs. Turkish officials highlight President Tayyip Erdoğan's visit to Mogadishu in January 2015 and on June 3, 2016. To them, these visits illustrate the importance of Turkey-Somali relations to Erdoğan's administration and signal the country's strong commitment to Somalia.

\section{Response and Perceptions of Somalis}

The Somali response to these myriad of Turkish activities and actors has been generally positive. Turkey's approach is seen as practical; their projects are tangible and of good quality, say most Somalis. "They brought orphanages, education. The best hospital was built by them. They train and build capacity, service delivery and business." 15 Through such projects, people feel that Turkey has contributed to the rejuvenation of the war-torn Mogadishu: "Look at the airport, for a country that has been out of touch for 25 years to have that kind of airport ... They are planning to build- have built roads, the Turkish. They brought this town back."16 This sentiment is shared by many interviewees. The Somali Ambassador to Turkey has stated that the "(Turks) ha(ve) returned a sense of normalcy to people, which is necessary." 17 Turkey's activities are credited with helping 
to change the narrative around Somalia as a failed state and the image of Mogadishu as a no-go-area. In particular, Turkey's approach has challenged the Nairobi-based model of long-distance aid that many traditional donors and international organizations have used for Somalia.

From a Somali perspective, Turkey is distinguished from other actors, even African states, by its impact on the ground, "The Turkish move around freely with no protection, no guns, nobody else can do that."18 The visibility of both Turkish projects and personnel on the ground is perceived as a successful aspect of their approach, "They (the Turkish) are not politically visible, they are in the community and that is the most important aspect-a community-centered approach." ${ }^{19}$ The communitycentered projects of Turkey are felt to positively contribute to peacebuilding. According to a Somali civil society actor, Turkey "provides for basic needs. Terrorists recruit younger people with no hope for the future but through providing the basics, the Turkish help to mitigate the allure of what the terrorists promise." 20 This sentiment is reiterated by the Somali Ambassador to Turkey, who believes that Turkey's maximum value is in scholarships and programs which have provided opportunities for Somali youth. $^{21}$

Despite the expansion of some projects to other parts of the country, Turkey's engagement in Somalia remains overwhelmingly focused on Mogadishu. With few exceptions, the benefits of these programs have been felt primarily by residents in Mogadishu. If the goal of these projects is to support the legitimacy and stability of the Federal Government, then it is geographically limited. Given the historical perception of Mogadishu as the center of patronage and oppression is still potent, Turkey risks being perceived as biased toward the capital. The potential negative implications of this have already been felt with Somaliland parties implying Turkey favoritism of the Federal Government's goal of a united Somalia.

In Somalia, Turkish nationals were seen through the prism of fellow coreligionist and not as another foreign power pursuing its own interest. This has started to change. A criticism levied by Somalis is that Turkish state agencies and business could do more to hire local people, "They are all Turkish companies not Somali private sector, we have nothing to do with it." ${ }^{22}$ While there are no numbers to verify these claims, the perception that Turkish entities are excluding Somalis is significant. If Turkish state agencies and companies were importing Turkish workers to work on Turkish projects, it would create an insular dynamic that does not benefit 
local communities or youth. While such an approach may avoid some local conflict actors such as gatekeepers, it would also deprive communities of economic opportunities that could support peacebuilding and undermine the capacity-building efforts of Turkish state actors.

Somalis also highlight interstate conflict at the international level between Turkey and other states. In particular, the specter of the Somali state as a source of personal patronage reemerges in the minds of Somalis regarding the controversy over the awarding of Mogadishu Port tender to a Turkish company: "There was no transparency in the procurement of the tender for the port, which resulted in suspicions of foul play by the West. The Turkish were criticized as not being honest." 23 While donor officials stress that there is and must be international cooperation on Somalia, this does not allay the perception among Somalis that "( $t$ ) here is no coordination between the West and the Turkish which creates conflict." ${ }^{24}$ International rivalry over business and contracts is a legitimate concern for Somalis given the history of the country and its susceptibility to regional and global shifts.

\section{Other Actors in Somalia}

There are a range of actors and countries engaged in Somalia. These include neighbors, donors, as well as new actors. When asked, however, which states they believe were conducting peacebuilding activities in Somalia, interviewees identified only Turkey. Other notable countries such as the UAE and, to a lesser extent, China were identified by interviewees as relatively new actors working in Somalia but not on peacebuilding. China is a relatively new actor, opening a small Embassy in the Jazeera Palace Hotel in Mogadishu in 2014. While China's activities in Somalia are minor compared to its ventures in other African countries, it has allegedly signed a number of trade deals, mostly recently with Puntland, to conduct oil explorations (Garowe Online 2016).

The Gulf States, in particular the UAE, were identified as another set of actors that are increasingly influential. ${ }^{25}$ The UAE is reported to be focusing on the provision of basic commodities and services, similar to Turkey. However, there exists a perception that the UAE is attempting to compete with Turkey in order to gain influence and visibility (Somali Peace Line 2016). This has allegedly meant that although actors from the UAE are welcome, many are wary of their motives. The UAE's activities in Somalia have not been without controversy. It is alleged that it has 
been providing heavy ammunition to Puntland, Jubaland, and South West State. ${ }^{26}$ The UAE plans to establish a military base in Somaliland and has signed a 30-year contract to manage its largest port, Berbera (Maina and Ibrahim 2017). This has been criticized as contradicting the sovereignty and integrity of Somalia (Radion Dalsan 2017), in which Somaliland is seen as a region of the country.

Local Somali actors that were interviewed clearly distinguished between the activities of states and non-state actors. In describing the activities of organizations such as the World Bank and the European Union, it was stated that they are service providers and focus primarily on systems. ${ }^{27}$ Examples of these systems were cited as human rights, accountability, transparency, and good governance. This was contrasted to the approach of states that are perceived to be more practical in their engagement. ${ }^{28}$

Somali civil society members interviewed stated that the support from African states is not as welcome as that from Turkey, the Gulf States, and some Asian countries. In fact, it was stated in one interview that often other Africans are grouped with state actors from the Global North. ${ }^{29}$ The main reason for this appears to be the historical tensions between Somalia and her neighbors, especially Ethiopia and Kenya. It was stated that local dynamics come into play and while on paper it appears that Al-Shabaab is being undermined, recruitment levels remain high. According to interviewees, Somalis feel betrayed by the African continent, particularly the African Union, which has permitted perceived interference from these regional actors who are believed to be pursuing anti-Somali agendas. Somali interviewees allege that the presence of peacekeepers from these regional powers has created a conflict of interest. ${ }^{30}$

AMISOM is considered a controversial force by many Somali respondents. Established in 2007, its mission, among others, is to reduce the threat of Al-Shabaab and provide security to enable stabilization, reconciliation, and peacebuilding processes in Somalia. The inclusion of Ethiopian and Kenyan troops has proved controversial and is a source for the distrust around AMISOM. However, in some instances, AMISOM itself has become a source of conflict. AMISOM troops have faced accusations of discrimination, rape, assault, sexual exploitation, and the killing of Somali civilians (Human Rights Watch 2015). For example, in July 2015, AMISOM troops were accused of killing six family members, as they were celebrating a wedding in the coastal city of Merka (Human Rights Watch 2015). These actions have made AMISOM unpopular in Somalia (Somali Peace Line 2016). Some AMISOM tactics have also alienated the mission 
from the very people they are supposed to protect. Somali interviewees mentioned that AMISOM troops frequently target Somali youth, particularly young men in Mogadishu, rounding them up and interrogating them on whether they are part of Al-Shabaab. Somali respondents noted that these actions have in fact turned some youth toward the group (Somali Peace Line 2016).

Perceptions are important, and they matter even more in fragile environments such as Somalia. As in most conflict-affected states, a large number of external actors are engaged activities in the country. Much work has been done to improve the livelihoods of Somalis. The effect of these many activities, initiated by different actors with divergent motivations and goals, can be very damaging given the conflict dynamics in Somalia. The motives behind the delivery of this support are not always transparent, and consequently benign intentions can be negatively perceived, as some of observations from Mogadishu confirm.

\section{Conclusion}

It is clear that the situation in Somalia is extremely complex and fragile. There are many latent issues that are not easily perceived from the outside. Statebuilding efforts in Somalia, which are an inherent conflict-riddled process, are a source of tension with disagreement over the structure of the Somali state. Another latent issue is the fragility of state institutions themselves that are unable to contain and address conflict through processes and systems. This leads political or business disagreements to spread to the public sphere. The inability of the Somali state to protect and support its citizens is also another issue which pushes civilians to seek alternative sources of power and survival.

In this complex and fragile context, the number and diversity of actors working in Somalia, from states to international institutions, and NGOs, with different values, approaches, and priorities, can cause harm. Based on the information gathered from the interviews, the approach of some actors in Somalia, such as the UAE, Ethiopia, Kenya, and AMISOM, is distrusted by Somalis. ${ }^{31}$ A noteworthy point is the fact that rather than being the most welcome in Somalia, some actors from other African states are often the least welcome. This is important in highlighting that the sentiments and perceptions of the local population in environments emerging from conflict play a big role in the success of peacebuilding initiatives. 
Not all activities conducted in the name of building peace appear to be contributing toward this objective. In the crowded donor environment and the fragile security situation in Somalia, the level of coordination and cooperation required for donors to be conflict sensitive is almost impossible without stifling the efficiency, aptness, and therefore effectiveness of programs. This is one of the main differences in the approach of traditional donors and that of other recent actors in Somalia. As previously mentioned, while traditional actors are said to focus more on systems, checks and balances, new actors such as the UAE and Turkey appear more concerned with the quick delivery of products or services. One interviewee stated that Somalis value tangible projects, and the problem for traditional donors is that systems cannot appear overnight and as a result of their focus on this, less is expected from them. ${ }^{32}$

Turkey's peacebuilding initiatives in Somalia highlight important alternative approaches, while offering vital lessons for all stakeholders to improve upon. The Somalia case study reveals several best practices, implemented by the Turkish state and its agencies that may be applied to other post-conflict reconstruction settings. Deployment of personnel in conflict-affect areas, consulting and responding quickly to stakeholder's and recipient's needs, refraining from securitizing and attaching conditions to aid, avoiding middle-men or brokers in order to avert security risks, engaging local partners, and not overcrowding the fragile institutions of the host country's vital bureaucracy are some of the approaches that Turkey brings to the spectrum. Some of these modes of engagement are similar to those espoused by traditional donors. However, while traditional donors appear to become stalled in the processes of ensuring principles are followed Turkey shows more flexibility and openness to changing procedures to meet the goal.

The Somali case study has also affirmed that there is still room for improvement for Turkey's peacebuilding activities in Somalia. The bilateral engagement on the ministerial level with Somali entities, without informing other Turkish state organizations, leads to overcrowding of the theater and waste of resources. Although Turkey has taken concrete steps to address some of these issues by coordinating some of its efforts with the international community and organizations, on a domestic level interagency cooperation still lags. Worse, institutional and legislative remedies to unravel this knot linger. Therefore, Turkey should use the Somalia case to single out some of its coordination issues and devise a solution that can 
be generalized to uproot similar problems that recur in Turkey's other overseas missions.

Turkey's diplomatic and humanitarian presence in Somalia demonstrates more than anything the resolve of rising powers to supporting fragile states in reconstruction. Somalia, contemplated by many as risky for humanitarian work, indicates the resolve of new actors in hedging the risks and intervening not just where there is peace to keep. This is quite in line with recommendations from the UN Advisory Panel for the review of the Peacebuilding Architecture, which posits that peacebuilding should cut across the conflict spectrum and not only come when normalcy has been established.

\section{Notes}

1. Interview with Turkish diplomat, 2014.

2. Interview with Somali civil society actor, 2015.

3. Interview with Afghan and Somali officials, Istanbul, 2016.

4. Interview with Turkish diplomats, 2015.

5. Ibid.

6. Interview with Turkish officials, 2015.

7. Interview with Dr. Kani Torun, Istanbul, 2014.

8. Interview with Turkish officials, 2015.

9. Ibid.

10. Ibid.

11. Interview with a senior executive from the Turkish Red Crescent on August 26, 2015.

12. Ibid.

13. Ibid.

14. Ibid.

15. Interview with Somali civil society actor, 2015.

16. Interview with official at the Office for Diaspora Affairs, Mogadishu, 2015.

17. Part of speech by Ambassador Abdullahi Mohamed Ali, Somali Ambassador to Turkey, Istanbul, 2015.

18. Interview with official at the Office for Diaspora Affairs, Mogadishu, 2015.

19. Interview with Somali civil society actor, 2015.

20. Ibid.

21. Part of speech by Ambassador Abdullahi Mohamed Ali, Somali Ambassador to Turkey, Istanbul, 2015.

22. Interview with official at the Office for Diaspora Affairs, Mogadishu, 2015.

23. Interview with Somali civil society actor, 2015.

24. Ibid. 
25. Ibid.

26. Ibid.

27. Interview with official at the Office for Diaspora Affairs, 2015.

28. Interview with Somali civil society actor, 2015.

29. Ibid.

30. Ibid.

31. Ibid.

32. Ibid.

\section{REFERENCES}

Achilles, Kathryn, Onur Sazak, Thomas Wheeler, and Auveen Woods. 2015. Turkish Aid Agencies in Somalia: Risks and Opportunities for Building Peace. Istanbul: Istanbul Policy Center.

Arman, Abukar. 2017. Blue Skies over Somalia. Al Jazeera. Accessed February 12, 2017. http://www.aljazeera.com/indepth/opinion/2017/02/blue-skiessomalia-170212083445301.html

Bekar, Olgan. 2016. Remarks at the Conference Entitled "Rising Powers and Peacebuilding: Innovative Approaches to Preventing Conflict and Sustaining Peace.” Istanbul Policy Center, Istanbul, May 23.

Balthasar, Dominik. 2013. Somaliland's Best Kept Secret: Shrewd Politics and War Projects as Means of State-Making. Journal of Eastern African Studies 7(2): 218-238.

Daily Sabah. 2017. Turkey gives \$122 Million in Humanitarian Aid to Somalia. Daily Sabah, March 9. Accessed March 9, 2017. https://www.dailysabah. com/africa/2017/03/09/turkey-gives-122-million-in-humanitarian-aid-tosomalia

Duffield, Mark. 2010. Risk-Management and the Fortified Aid Compound: Everyday Life in Post-Interventionary Society. The Journal of Intervention and Statebuilding 4(4): 453-474.

Favori LLC. n.d.. http://www.favorillc.com/

Garowe Online. 2016. Somalia: President Ali Signs Deals with a Chinese Company. Garowe Online, November 28. Accessed March 1, 2017. http://www. garoweonline.com/en/news/puntland/somalia-president-ali-signs-dealswith-chinese-companies

Geeska Africa Online. 2015. Uganda: AMISOM Peacekeeper's Position to Prolong AU Mission to Earn Money. http://www.geeskaafrika.com/uganda-amisompeacekeepers-position-to-prolong-au-mission-to-earn-money/10086/\#sthash. CMys14dp.dpuf

Global Humanitarian Assistance. 2014. Somalia Donors. Accessed February 28, 2017. http://www.globalhumanitarianassistance.org/countryprofile/somalia\#tab-donors 
Harper, Mary. 2012. Getting Somalia Wrong: Faith, War and Hope in a Shattered State. London: Zed Books.

Hearn, Sarah. 2016. Independent Review of the New Deal for Engagement in Fragile States Cooperation. New York: NYU Center on International Cooperation.

Human Rights Watch. 2015. Somalia: AU Forces Linked to Wedding Killings. Accessed February 25, 2017. https://www.hrw.org/news/2015/08/13/ somalia-au-forces-linked-wedding-killings

Hurriyet Daily News. 2016. Turkey Finalizes Military Training Base in Somalia. October 1. Accessed October 14, 2016. http://www.hurriyetdailynews.com/ turkey-finalizes-military-training-base-in-somalia.aspx? PageID $=238 \& N I D=10$ 4468\&NewsCatID $=510$

International Crisis Group. 2012. Assessing Turkey's Role in Somalia. ICG Africa Briefing No. 92. http://www.crisisgroup.org/en/regions/africa/horn-ofafrica/somalia/b092-assessing-turkeys-role-in-somalia.aspx

Lough, Richard. 2012. INSIGHT-Turkey Tries Out Soft Power in Somalia. Reuters June 3. Accessed January 11, 2016. http://www.reuters.com/article/ somalia-turkey-idUSL5E8GP2LP20120603

Maina, Judy and Jamal Ibrahim. 2017. UAE Seeks to Open Military Base in Somaliland. All East Africa, January 11. Accessed March 2, 2017. https:// www.alleastafrica.com/2017/01/11/uae-seeks-to-open-military-base-insomaliland/

Menkhaus, Ken. 2014. If Mayors Ruled Somalia: Beyond the State-Building Impasse. Nordic Africa Policy Institute, Policy Note 2. http://www.nai.uu.se/ news/articles/2014/04/29/154351/index.xml

OECD. 2015. Aid Statistics, Recipients at a Glance. http://www.oecd.org/countries/somalia/recipientcharts.htm

Presidency of the Turkish Republic. 2016. Somalia has Become a Symbol of the Relations We Wish to Establish With Our Brothers in Africa. Accessed March 5 , 2016. http://www.tccb.gov.tr/en/news/542/39918/somalia-has-become-asymbol-of-the-relations-we-wish-to-establish-with-our-brothers-in-africa.html

Radion Dalsan. 2017. Somalia Accuses UAE of Destabilising Country Terms Military Deal With Somaliland Illegal. Accessed February 16, 2017. http:// radiodalsan.com/en/somalia-accuses-uae-of-destabilising-country-termsmiliatry-deal-with-somaliland-illegal/

Sazak, Onur, Thomas Wheeler, and Auveen Woods. 2015. Turkey and Somalia: Making Aid Work for Peace. Safer World Briefing.

Somali Peace Line. 2016. Transforming Conflict and Violence in Somalia through Effective Community Engagement. Workshop at the Istanbul Policy Center. Istanbul.

Sucuoglu, Gizem, and Jason Stearns. 2016. Turkey in Somalia: Shifting Paradigm of Aid. Report No. 24. Pretoria: South African Institute of International Affairs. 
The Somali Investor. 2015. New Management at Albayrak Port in Mogadishu Creates Hope. Accessed February 16, 2016. http://somaliainvestor.so/index. $\mathrm{php} /$ travel/item/109-new-management-at-albayrak-port-in-mogadishu-creates-hope

Today Zaman. 2012. Turkey-Somalia Military Agreement Approved. November 9. http://www.todayszaman.com/news-297699-turkey-somalia-military-agreementapproved.html

Turkish Development and Coordination Agency. 2013. 2012 Annual Report. Ankara.

—. Turkish Development Assistance 2014 Report. http://www.tika.gov.tr/ en/publication/list/turkish_development_assistance_reports-24

- 2016. 2014 Annual Report. Ankara.

Turkish Statistics Agency. 1996-2017. Exports by Country. Accessed February 28, 2017. http://www.tuik.gov.tr/PreIstatistikTablo.do?istab_id=624

UNHCR. 2016. Somalia: Overview Situation Report. Accessed January 20, 2017. http://data.unhcr.org/horn-of-africa/country.php?id=197

Wasuge, Mahad. 2016. Turkey's Assistance Model in Somalia: Achieving Much with Little. Mogadishu: Heritage Institute for Policy Studies. http://www. heritageinstitute.org/wp-content/uploads/2016/02/Turkeys-AssistanceModel-in-Somalia-Achieving-Much-With-Littlel-1.pdf

Onur Sazak is an advocacy and coordination manager at Support to Life and a Ph.D. candidate in political science at Sabancı University, Istanbul.

Auveen Elizabeth Woods is a researcher, Istanbul Policy Center, Sabanc1 University, Istanbul.

Open Access This chapter is licensed under the terms of the Creative Commons Attribution 4.0 International License (http://creativecommons.org/licenses/ by $/ 4.0 /$ ), which permits use, sharing, adaptation, distribution and reproduction in any medium or format, as long as you give appropriate credit to the original author(s) and the source, provide a link to the Creative Commons license and indicate if changes were made.

The images or other third party material in this chapter are included in the chapter's Creative Commons license, unless indicated otherwise in a credit line to the material. If material is not included in the chapter's Creative Commons license and your intended use is not permitted by statutory regulation or exceeds the permitted use, you will need to obtain permission directly from the copyright holder.

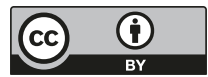

